\title{
РТУТЬ КАК ИНДИКАТОР СОВРЕМЕННОЙ РУДООБРАЗУЮЩЕЙ ГАЗО-ГИДРОТЕРМАЛЬНОЙ СИСТЕМЫ (КАМЧАТКА)
}

\author{
(C) 2014 г. С. Н. Рычагов*, А. А. Нуждаев*, И. И. Степанов** \\ * Институт вулканологии и сейсмологии ДВО РАН \\ 683006 Петропавловск-Камчатский, бульвар Пийпа, 9 \\ E-mail:rychsn@kscnet.ru,envi@kscnet.ru \\ **ОАО “Александровская опытно-методическая экспедиция” \\ 601650 Александров, Владимирская обл., Красный пер., 6 \\ E-mail: stepanovvi@mail.ru \\ Поступила в редакцию 01.04. 2011 г. \\ Принята к печати 09.04.2012 г.
}

\begin{abstract}
Обсуждаются новые данные о распределении ртути во вмещающих вулканогенно-осадочных и магматических горных породах, гидротермально-метасоматических породах и всех типах современных новообразований (гидротермальных глинах, аргиллизированных почвенно-пирокластических отложениях, кремнистых и лимонит-гематитовых плащах, донных осадках, солевых выпотах различного состава, и др.), характерных для зоны гипергенеза геотермальных месторождений. На примере Нижне-Кошелевского (пародоминирующего) и Паужетского (водного типа) геотермальных месторождений, термальных полей Кошелевского вулканического массива и Камбального вулканического хребта (Южная Камчатка) показано значение ртути как элемента-индикатора температуры, фазового состояния и динамики гидротерм, интенсивности процессов аргиллизации пород, относительного возраста (зрелости) геотермальных месторождений и термоаномалий.
\end{abstract}

Ключевые слова: ртуть, газо-гидротермальная система, геотермальное месторождение, зона гипергенеза, гидротермально-метасоматические образования.

DOI: $10.7868 / \mathrm{S} 001675251312008 \mathrm{X}$

\section{ВВЕДЕНИЕ}

Изучение поведения ртути в геологических структурах остается актуальным, в частности, для решения задач в области геодинамики зоны перехода океан-континент и районов тектоно-магматической активизации, совершенствования методик поиска различных рудных и нефтегазовых месторождений, картирования флюидопроводящих разломов, выявления участков техногенного заражения атмо, био- и гидросферы в районах мегаполисов и оценки воздействия этих новообразованных геохимических аномалий на гидрогеологические и др. природные системы. Решению отмеченных задач может помочь исследование геохимии $\mathrm{Hg}$ в современных гидротермальных системах и геотермальных месторождениях, которые отличаются от других геологических объектов высокой динамикой газов и гидротермальных растворов и, соответственно, характеризуются большой подвижностью химических элементов, переносимых в составе теплоносителя. Исследования в этой области показали, что ртуть служит индикатором температурного режима и структуры проницаемости гидротермальных систем и геотермальных (рудных) районов [1-3]. Наши работы обращают внимание на различный характер поведения $\mathrm{Hg}$ в гидротермальных системах прогрессивного и регрессивного этапов развития, а также в разных типах минеральных новообразований зоны гипергенеза геотермальных месторождений [4-6]. Детальное изучение особенностей распределения $\mathrm{Hg}$ в гидротермальных глинах, кремнистых и железистых осадках, почвенно-пирокластических отложениях, развитых внутри и за пределами термальных полей, донных осадках, солевых отложениях различного состава и в отдельных минералах - все это позволит создать основу модели геохимического цикла ртути в современных и древних рудообразующих гидротермальных системах.

\section{МЕТОДИКА ИССЛЕДОВАНИЙ}

На основе исследования опорных геологических разрезов и керна глубоких скважин, проходки шурфов и картировочных скважин на геотермальных полях, систематического опробования образующихся на дневной поверхности кремнистых и др. отложений, изучены все типы неизмененных горных пород и гидротермально-метасоматических новообразований, развитых на территории Паужетско-Камбально-Кошелевского геотермального (рудного) района Южной Камчатки. Описание пород и новообразований приводится ниже. Масса проб составляла, в среднем, 1 кг. Подготовка проб выполнена стандарт- 


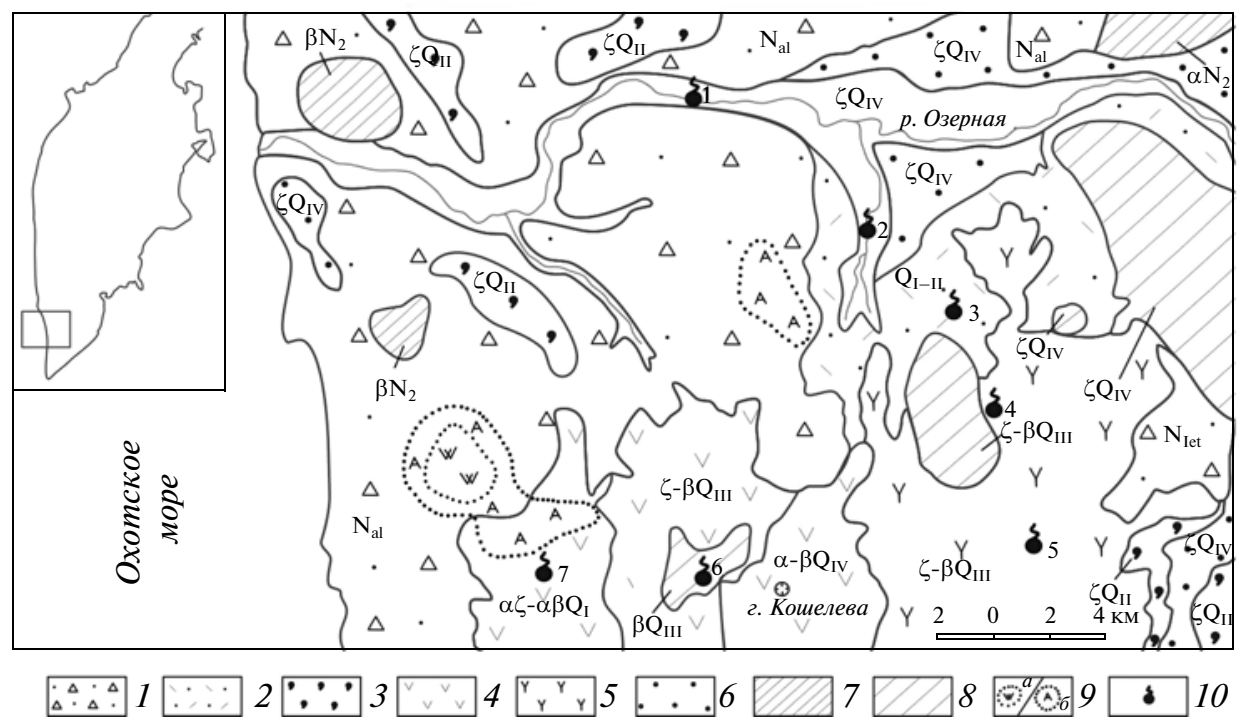

Рис. 1. Схематическая геологическая карта Паужетско-Камбально-Кошелевского геотермального (рудного) района, Южная Камчатка. Составлена на основе обобщения материалов научных исследований и государственных геологических съемок масштаба $1: 200000.1$ - Вулканиты алнейской серии (лаво-пирокластические нерасчлененные отложения фундамента неогенового возраста, $\mathrm{N}_{\mathrm{al}}$ ) и эталонской свиты (туфопесчаники, туфоалевролиты, туфы, гравелиты, конгломераты миоценового возраста, $\mathrm{N}_{1 \mathrm{t}}$ ) $; 2$ - вулканогенно-осадочные отложения паужетской свиты (туффиты нижне-среднечетвертичного возраста, $\mathrm{Q}_{\mathrm{I}-\mathrm{II}}$ ); 3 - игнимбриты (дациты, риодациты среднечетвертичного возраста, $\left.\zeta \mathrm{Q}_{\mathrm{II}}\right) ; 4$ - лавовые комплексы Кошелевского вулканического массива: нижнечетвертичный андезидацитов-андезибазальтов $\left(\alpha \zeta-\alpha \beta \mathrm{Q}_{\mathrm{I}}\right)$, среднечетвертичный контрастного состава (от дацитов до базальтов, $\left.\zeta-\beta \mathrm{Q}_{\mathrm{II}}\right)$, верхнечетвертичный андезибазальтов $\left(\alpha-\beta Q_{\mathrm{IV}}\right) ; 5$ - вулканиты Камбального хребта (лавы, пирокластические потоки, экструзии от кислого до основного состава среднечетвертичного возраста, $\left.\zeta-\beta \mathrm{Q}_{\mathrm{III}}\right) ; 6$ - пемзовые отложения дацитов верхнечетвертичного возраста $\left(\zeta \mathrm{Q}_{\mathrm{IV}}\right) ; 7$ - субвулканические и экструзивные тела базальтов и андезитов неогенового возраста $\left(\beta \mathrm{N}_{2}, \alpha \mathrm{N}_{2}\right)$, 8 - экструзивно-субвулканические тела среднечетвертичного возраста основного и контрастного состава $\left(\beta \mathrm{Q}_{\mathrm{III}}\right.$, $\left.\zeta-\beta \mathrm{Q}_{\mathrm{III}}\right)$ и верхнечетвертичного возраста кислого состава $\left(\zeta \mathrm{Q}_{\mathrm{IV}}\right) ; 9-$ поля гидротермально измененных пород: $a-$ вторичных кварцитов, $\sigma$ - аргиллизитов; 10 - основные современные термоаномалии района: 1 - Первые Горячие Ключи (Пионерлагерь), 2 - Вторые Горячие Ключи (Паужетское месторождение), 3 - Северо-Камбальная, 4 - ЦентральноКамбальная, 5 - Южно-Камбальная, 6 - Верхне-Кошелевская, 7 - Нижне-Кошелевская.

ным способом. Образцы высушивались при комнатной температуре (не превышающей $\left.30^{\circ} \mathrm{C}\right)$. Навеска в $100 \pm 10$ граммов истиралась в чугунной ступке и просеивалась с помощью комплекта лабораторных сит, изготовленных из нержавеющей стали. На аналитические исследования представлена фракция 0.1-0.2 мм, масса которой для каждой пробы составила $50 \pm 5$ граммов. Определения содержания ртути выполнены в Институте геохимии им. А.П. Виноградова СО РАН методом беспламенной атомно-абсорбционной спектрометрии, прибор РА-915; и в Институте вулканологии и сейсмологии ДВО РАН атомно-флюоресцентным методом с диффузионным разделением, прибор “Меркурий 3М”. Погрешность определений обоими методами составляет, в среднем, 10-30\%. Количество проб - более 500, число проб для контрольных измерений -28 .

\section{ХАРАКТЕРИСТИКА ОБЪЕКТОВ ИССЛЕДОВАНИЙ}

Паужетско-Камбально-Кошелевский геотермальный (рудный) район, на примере которого выполнена работа, входит в состав Южно-Камчатской геотермальной провинции [7]. Район отождествляется с вулканическим центром, представленным крупной тектоно-магматической структурой, эволюционирующей с раннего олигоцена по голоцен [8], рис. 1. Породы района типичны для островодужного комплекса: вулканогенно-осадочные (туффиты от тонко- до грубообломочных), изверженные (лавы и туфы) и интрузивные (от крупных субвулканических тел диоритов и габбродиоритов до силлов и даек андезибазальтов). Преобладающий состав пород средний, в меньшей степени основной и кислый, что характерно для андезитового вулканизма. Район включает три основные геологические структуры, определяющие его развитие, положение источников тепла и рудного вещества, гидродинамику и формирование отдельных геотермальных аномалий: Паужетскую гидротермально-магматическую систему, Камбальный вулканический хребет (тектоно-магматическое поднятие) и Кошелевский вулканический массив.

Паужетская гидротермально-магматическая система расположена в одноименной вулкано-тектонической депрессии четвертичного возраста, размером в плане $20 \times 25$ км [9]. Восточный фланг депрессии осложнен тектоно-магматическим под- 
нятием Камбального вулканического хребта. Поднятие контролирует три группы современных термальных полей на протяжении более 15 км. На юге эту структуру замыкает Камбальный вулкан, относящийся к действующим.

Кошелевский вулканический массив образован за счет эволюции периферического магматического очага, сформировавшегося на пересечении крупнейших южнокамчатских разломов. Массив сложен постройками пяти вулканов возрастом от нижнечетвертичного до голоценового, состав пород преимущественно средний [10]. Это типичный, но сложный андезитовый вулкан, локализованный на сочленении камчатского и курильского сегментов островной дуги, разделенных сквозькоровыми разломами на крупные региональные тектонические блоки. Сквозькоровый характер разломов подтверждается геофизическими данными, результатами изотопно-геохимических исследований, сведениями о наличии в составе восходящих потоков метана и тяжелых углеводородов [10-14].

Непосредственными объектами наших исследований послужили современные термальные поля района (Верхне- и Нижне-Кошелевское, ВерхнеПаужетское, Южно-Камбальное Центральное) и Паужетское и Нижне-Кошелевское геотермальные месторождения.

Паужетское геотермальное месторождение является одним из наиболее изученных на Камчатке $[9,15$, 16]. Его установленная мощность составляет $11 \mathrm{MBT}_{\ni}$ (электрической мощности), прогнозная $\geq 60 \mathrm{MBT}_{\ni}$ В расчете на 100 лет эксплуатации [17]. На месторождении выделяется несколько поверхностных термоаномалий. Верхне-Паужетское термальное поле является наиболее крупным $(100 \times 150$ м в плане $)$. По данным бурения установлено, что геологическая структура этого участка представлена тектоно-магматическим поднятием четвертичного возраста, определяющим движение восходящего потока хлоридно-натриевых термальных вод и образование длительно эволюционирующей зоны перехода жидкость-пар [18]. Вследствие кипения гидротерм на глубине от 50 до 150 м в туфах и туффитах СреднеПаужетской подсвиты образованы гидротермальнометасоматические брекчии кварц-адулярового состава, к которым приурочены комплексные геохимические барьеры (Au, Ag, As, B, K, Li, Rb).

Нижне-Кошелевское геотермальное месторождение разведано в 1975-84 гг. Его прогнозные ресурсы оценены в 210 кг/с сухого пара или $90 \mathrm{MBT}_{\text {э }}$ [12]. Особенностью месторождения является наличие мощной зоны перегретого пара, расширяющейся на глубину более 1500 м. Это обстоятельство ставит его в ряд крупнейших пародоминирующих геотермальных месторождений Мира, таких как Лардерелло (Италия), Гейзерс (США), Матсукава (Япония), Камоджанг (Индонезия) [19]. Зона пара локализована над субинтрузивным телом диоритов, вскрытых скважинами в интервале 1000-1500 м [12]. На дневной поверхности зона пара образует компактную $(250 \times 500$ м $)$ одноименную термоаномалию мощностью 25 Гкал/с. Повышенный интерес к месторождению возник в связи с определением в его газонасыщенных термальных водах метана и тяжелых углеводородов, вплоть до $\mathrm{C}_{7} \mathrm{H}_{12}$, а также “мантийного" гелия [13, 14, 20]. Предварительные исследования зоны гипергенеза месторождения поз-волили наметить связь между глубинными геотермальными и приповерхностными минералогогеохимическими и гидрогеохимическими процессами [21, 22]. Верхне-Кошелевское термальное поле (термоаномалия мощностью 50 Гкал/с [10]) расположено в центральной части Кошелевского вулканического массива в эрозионном кратере вулкана Валентин, приурочено к контактовым зонам остывающего экструзивно-субвулканического комплекса андезидацитов и характеризуется более высокими $P-T$ параметрами разгружающегося здесь паро-газового флюида [10, 20].

Южно-Камбальное термопроявление из всех геотермальных структур Камбального хребта наиболее приближено к вулкану и предположительно имеет связь с его периферическим магматическим очагом [23]. Оно состоит из трех крупных термальных полей, каждое из которых отличается геологическим строением и морфоструктурой. Южно-Камбальное Центральное термальное поле (ЮКЦ) локализовано в кольцевой структуре диаметром 500-600 м, представляющей собой кратер верхнечетвертичного андезитового вулкана. Разгружающиеся здесь термальные воды отличаются высокими содержаниями Аu и низкими отношениями ${ }^{87} \mathrm{Sr} /{ }^{86} \mathrm{Sr}$, что указывает на наличие глубинного флюида, участвующего в формировании терм [24, 25]. Гидротермально измененные породы и глины этого поля также характеризуются высокими концентрациями $\mathrm{Au}, \mathrm{Ag}, \mathrm{Hg}$, щелочных металлов [9].

\section{ФИЗИКО-ХИМИЧЕСКАЯ ОБСТАНОВКА В ЗОНЕ ГИПЕРГЕНЕЗА

ГЕОТЕРМАЛЬНЫХ МЕСТОРОЖДЕНИЙ

На поверхности Паужетского и Нижне-Кошелевского геотермальных месторождений формируются кислые и слабо кислые сульфатные смешанного катионного состава $(\mathrm{Ca}-\mathrm{Na}-\mathrm{Mg}-\mathrm{K})$ и гидрокарбонатно-сульфатные аммониевые воды (табл. 1). Минерализация вод поверхностного формирования редко превышает 1 г/л. Отмечается щелочно-метальная и щелочно-земельная специализация вод геотермального района [26]. Глубинные воды являются щелочно-метальными борными хлоридно-натриевыми с минерализацией $\geq 3-5$ г/л (R-121/05 в табл. 1) или щелочно-земельными гидрокарбонатно-кальциевыми (НК-1/06 в табл. 1). Последний тип растворов характеризует зону смешения вод на глубине более 500-1000 м в структуре Нижне-Кошелевского месторождения. Для всех типов вод (глубинных, смешанных и поверхностно- 
го формирования) характерна кремниевая кислота в растворенной и коллоидной формах. Коллоидная форма играет большую роль в образовании кремнистых осадков (“гейзеритов") на поверхности термальных полей и в насыщении минералами кремнезема толщи аргиллизированных метасоматитов [27]. Эти процессы ведут к упрочнению пород, созданию дополнительного верхнего водоупора в структуре гидротермальных систем и их самоизоляции $[28,29]$. Термальные воды, разгружающиеся на поверхности Камбального хребта (ЮКЦ-1/05 в табл. 1) и Нижне-Кошелевской термоаномалии формируются с участием глубинных флюидов, о чем свидетельствуют низкие значения ${ }^{87} \mathrm{Sr} /{ }^{86} \mathrm{Sr}$ и высокие концентрации $\mathrm{Au}$, щелочных металлов и редкоземельных элементов [25]. Воды паужетских термальных полей формируются в результате активного взаимодействия смешанных нагретых паром сульфатно-гидрокарбонатно-кальциевых вод с породами и гидротермальными глинами, чем определяется их разнообразный состав и относительно высокая минерализация (до 1.0-1.5 г/л).

В состав газов входят: углекислый и угарный, сероводород, хлористый водород, водород, азот, метан и тяжелые углеводороды. Последние характерны для Нижне-Кошелевского геотермального месторождения, что дополнительно указывает на глубинный характер источника геотермального тепла и восходящего потока флюидов в этой геологической структуре.

Температуры разгружающихся на дневной поверхности гидротермальных растворов соответствуют условиям вскипания гидротерм и не превышают $98-100^{\circ} \mathrm{C}$. Глубинные термы формируются при температуре $200-220^{\circ} \mathrm{C}$ для нижнего водоносного горизонта Паужетского месторождения и 270$280^{\circ} \mathrm{C}$ для вскрытого уровня (1500 м от дневной поверхности) зоны перегретого пара Нижне-Кошелевского геотермального месторождения. Температура паро-газовой смеси достигает $120-130^{\circ} \mathrm{C}$ на устьях фумарол Нижне-Кошелевской и $150^{\circ} \mathrm{C}$ Верхне-Кошелевской термоаномалии [30]. Предполагается, что обе эти аномалии связаны гидродинамически [10] и входят в состав единой Кошелевской газо-гидротермальной системы, одной из наиболее мощных на Камчатке.

В зоне гипергенеза описанных выше геологогидрогеологических структур под влиянием активной циркуляции и смешения газонасыщенных растворов и пара образуются гидротермальные глины, кремнистые осадки, соли смешанного состава и другие гидротермально-метасоматические новообразования, подробная характеристика которых дана в работах $[6,21,22,31]$.

\section{ФАКТИЧЕСКИЙ МАТЕРИАЛ: \\ РАСПРЕДЕЛЕНИЕ РТУТИ В РАЗЛИЧНЫХ ТИПАХ ТВЕРДЫХ ОТЛОЖЕНИЙ}

Горные породы. Изучено распределение ртути в лавах андезитов и базальтов, интрузивных поро- дах среднего и основного составов, туфах и туффитах Курило-Камчатского и Альпийского регионов. Альпийский регион представляет интерес в связи с активизацией тектоно-магматических процессов и образованием центров базальтового вулканизма в плиоцен-нижнечетвертичное время [32]. Породы этих центров представлены лавами, субвулканическими образованиями, туфами и туффитами различной размерности обломков от основного до среднего составов [33]. Кроме того, центры формировались в пределах крупных артезианских бассейнов и являются источниками тепла для расположенных в восточной части Альпийского региона длительноживущих (с плиоцен-четвертичного времени по голоцен) гидротермальных систем. Все это предопределило актуальность сравнительного анализа характера распределения ртути в горных породах КурилоКамчатского и Альпийского регионов.

Уровень концентрации $\mathrm{Hg}$ в лавах андезитов и базальтов Паужетско-Камбально-Кошелевского геотермального (рудного) района Южной Камчатки соответствует фоновым содержаниям, которые составляют (1.0-3.8) × 10-6\% [34], табл. 2. Отдельные более высокие значения (до $15 \times 10^{-6 \%}$ ), вероятно, связаны с проявлением вторичных процессов в коре выветривания геотермальных районов. В частности, отмечается тенденция увеличения концентраций $\mathrm{Hg}$ в лавах андезитов, расположенных в пределах зон разрывных тектонических нарушений и затронутых вследствие этого процессами химического выветривания. Содержания $\mathrm{Hg}$ в базальтах Альпийского региона не превышают $0.6 \times 10^{-6} \%$. Имеющийся ряд данных по интрузивным породам также свидетельствует в пользу низких концентраций ртути в них. Содержание $\mathrm{Hg}$ в туфах и туффитах Южной Камчатки и Альпийского региона, в целом, несколько выше, чем в лавах или интрузивных породах, но также отвечает фоновым значениям.

Таким образом, подтверждаются полученные ранее данные о фоновом уровне концентраций ртути в неизмененных породах, слагающих основу геологических структур геотермальных районов [3-6].

Гидротермально измененные породы, в целом, содержат повышенные концентрации $\mathrm{Hg}$. Пропилиты и аргиллизированные породы, расположенные вне зоны прямого воздействия современных гидротерм (в палеогидротермальных системах), характеризуются как низкими значениями $\mathrm{Hg}$, так и на порядок выше относительно фона (табл. 2). Последние проявляются в гематитизированных и брекчированных лавах и туфах. В зоне влияния современных гидротермальных растворов пропилитизированные и аргиллизированные туфы обогащены $\mathrm{Hg}$ - в среднем на 1.5-2 порядка выше фоновых значений для пород региона (табл. 2). Наиболее высокими значениями 


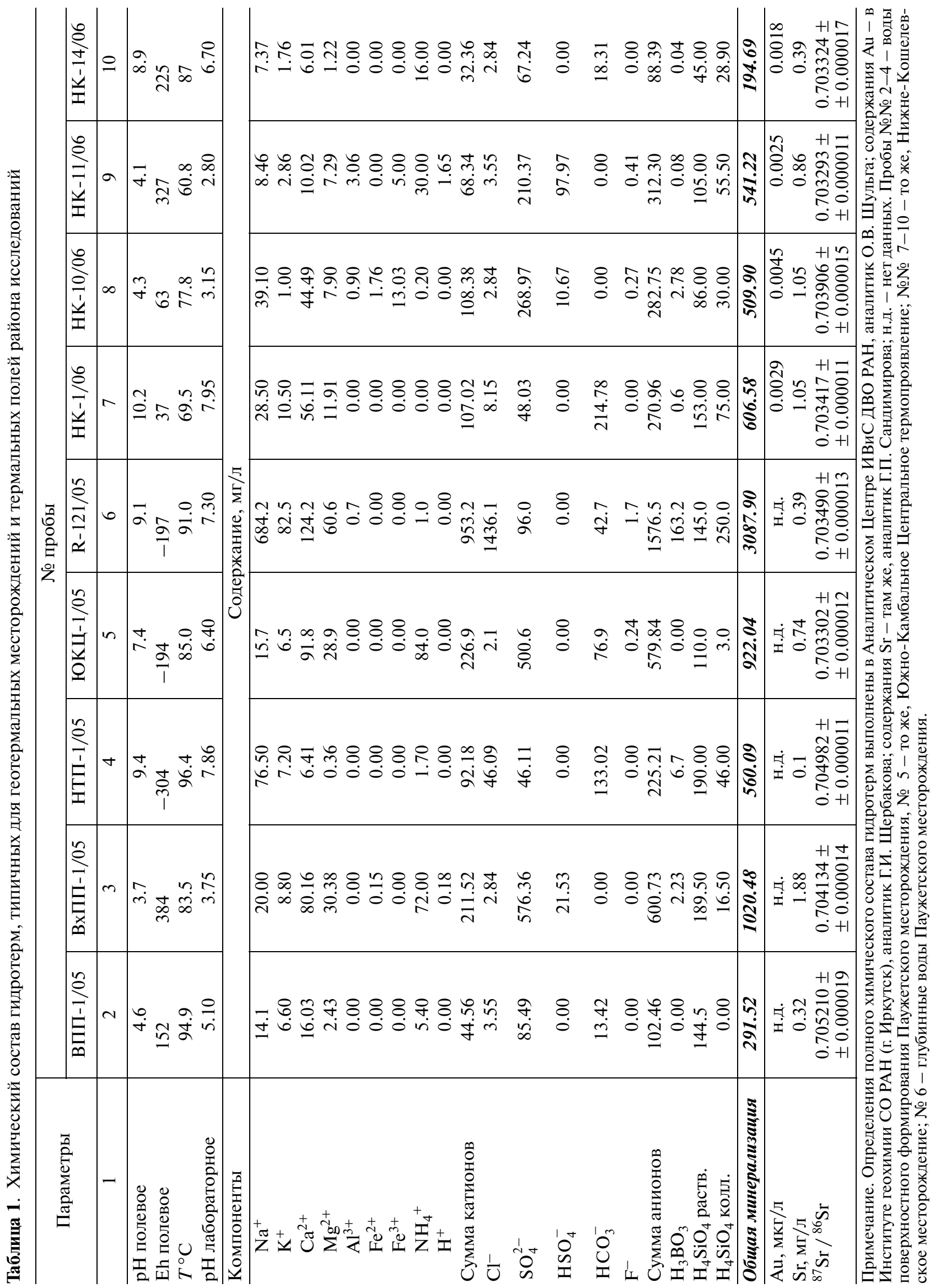

ГЕОХИМИЯ № 22014 
Таблица 2. Обобщенные данные по распределению ртути в горных породах и гидротермально-метасоматических новообразованиях Паужетско-Камбально-Кошелевского геотермального (рудного) района Южной Камчатки

\begin{tabular}{|c|c|c|c|c|c|c|}
\hline \multirow{2}{*}{\begin{tabular}{c|} 
№ \\
П.П.
\end{tabular}} & \multirow{2}{*}{\multicolumn{2}{|c|}{ Типы твердых отложений }} & \multicolumn{3}{|c|}{$\mathrm{Hg}, \times 10^{-6}$ мac. $\%$} & \multirow{2}{*}{$\begin{array}{l}\text { K-во } \\
\text { проб }\end{array}$} \\
\hline & & & миним. & максим. & средние & \\
\hline \multirow[t]{3}{*}{1} & \multirow{3}{*}{$\begin{array}{l}\text { Неизмененные } \\
\text { горные породы }\end{array}$} & Лавы & 0.2 & 15.0 & 1.7 & 60 \\
\hline & & Туфы, туффиты & 0.4 & 7.0 & 2.7 & 16 \\
\hline & & Интрузивные & 0.5 & 2.4 & 1.1 & 5 \\
\hline \multirow[t]{4}{*}{2} & \multirow[t]{4}{*}{\begin{tabular}{|l|} 
Гидротермально \\
измененные породы
\end{tabular}} & $\begin{array}{l}\text { Пропилитизированные и аргиллизированные, } \\
\text { из палеогидротермальных систем }\end{array}$ & 0.2 & 31.0 & 6.0 & 9 \\
\hline & & То же, из современных гидротермальных систем & 5.0 & 370.0 & 93.0 & 25 \\
\hline & & Вторичные кварциты и монокварциты & 0.7 & 580.0 & 82.0 & 27 \\
\hline & & Опалиты & 1.4 & 25.0 & 8.3 & 21 \\
\hline \multirow[t]{2}{*}{3} & \multirow{2}{*}{$\begin{array}{l}\text { Гидротермальные } \\
\text { глины }\end{array}$} & Глинистый субстрат & 2.2 & 7800.0 & 570.0 & 102 \\
\hline & & Образцы горных пород, извлеченные из глин & 0.8 & 1800.0 & 49.0 & 22 \\
\hline \multirow[t]{3}{*}{4} & \multirow[t]{3}{*}{$\begin{array}{l}\text { Почвенно-пирокла- } \\
\text { стические отложения }\end{array}$} & $\begin{array}{l}\text { Супесь и суглинок, аргиллизированные - в вер- } \\
\text { тикальном разрезе прогретой части Нижне-Ко- } \\
\text { шелевского нового термального поля (НКН) }\end{array}$ & 40.0 & 360.0 & 160.0 & 20 \\
\hline & & $\begin{array}{l}\text { То же, с признаками слабой аргиллизации, в вер- } \\
\text { тикальном разрезе на границе НКН }\end{array}$ & 26.0 & 140.0 & 33.0 & 5 \\
\hline & & \begin{tabular}{|l|} 
Подпочвенный горизонт на площади, включаю- \\
щий НКН - внутри и за его пределами
\end{tabular} & 9.0 & 2700.0 & 290.0 & 50 \\
\hline \multirow[t]{2}{*}{5} & \multirow{2}{*}{$\begin{array}{l}\text { Пирит, выделенный } \\
\text { из гидротермальных } \\
\text { глин }\end{array}$} & $\begin{array}{l}\text { Концентрат пирита, примеси др. минералов } \\
\text { представлены халцедоном, опалом, кварцем }\end{array}$ & 330.0 & 13000.0 & 4700.0 & 9 \\
\hline & & $\begin{array}{l}\text { Монофракции пирита, примеси включают также } \\
\text { лимонит, гематит, барит, др. минералы }\end{array}$ & 230.0 & 11000.0 & 2900.0 & 35 \\
\hline \multirow[t]{2}{*}{6} & \multirow[t]{2}{*}{\begin{tabular}{|l|} 
Кремнистые и кар- \\
бонатные отложения
\end{tabular}} & $\begin{array}{l}\text { Кремнистые осадки, образующиеся на изливе } \\
\text { термальных вод из скважин и сепараторов }\end{array}$ & 0.8 & 27.0 & 7.1 & 14 \\
\hline & & $\begin{array}{l}\text { Кремнистые и карбонатные отложения из тер- } \\
\text { мальных источников }\end{array}$ & 13.0 & 1800.0 & 250.0 & 20 \\
\hline \multirow[t]{2}{*}{7} & \multirow{2}{*}{\begin{tabular}{|l|} 
Солевые отложения \\
на термальных полях
\end{tabular}} & Соли сложного состава & 1.1 & 1300.0 & 95.0 & 16 \\
\hline & & Лимонит-гематитовые отложения & 0.5 & 7.9 & 3.1 & 7 \\
\hline 8 & \multicolumn{2}{|c|}{ Кремнисто-сульфидные корки из фумарол } & 17.0 & 290.0 & 100.0 & 14 \\
\hline 9 & \multicolumn{2}{|c|}{ Тяжелая фракция шлиховых проб аллювия термоаномалии } & 980.0 & 3800.0 & 2100.0 & 6 \\
\hline
\end{tabular}

Примечание. Определения выполнены в Институте геохимии им. А.П. Виноградова СО РАН, Аналитический сектор (зав. сектором С.И. Дриль), методом беспламенной атомно-абсорбционной спектрометрии, прибор РА-915, аналитики Л.Д. Андрулайтис и О.С. Рязанцева, п.П. 1-6, 8-9; и в Аналитическом Центре Института вулканологии и сейсмологии ДВО РАН атомно-флюоресцентным методом с диффузионным разделением, прибор “Меркурий 3М”, аналитик В.П. Коростелева, п.П. 5-7.

ртути выделяются пропилитизированные ксенотуфы, содержащие пирит, карбонаты, цеолиты. Устойчивыми высокими значениями выделяются кварц-адуляровые метасоматиты зоны перехода жидкость-пар (в среднем, (200-250) × 10-6\%). Ранее было определено, что эти породы в разрезе скважины К-13 Паужетского геотермального месторождения содержат также повышенные концентрации $\mathrm{Au}, \mathrm{Ag}, \mathrm{K}, \mathrm{B}, \mathrm{Li}, \mathrm{Rb}, \mathrm{Cs}$ [9] и образуются за счет высаживания криптокристаллического кварца и зерен адуляра в высокопористых туфах в процессе резкого снижения давления в геотермальном резервуаре и охлаждения раствора, содержащего коллоидную кремнекислоту. Начальная высокая пористость туфов многократно возрастает (до 50\% открытой пористости) вследствие активного выщелачивания основных компонентов и механического вымывания глинистых частиц, цеолитов и др. минералов из основной массы пород [35]. Остается нерешенным вопрос о механизмах осаждения ртути - в дефектных структурах пород и минералов (пустотах, порах, трещинах) или (и) вхождение в кристаллическую решетку минералов, что может происходить уже на первом этапе их кристаллизации вследствие захвата атомов $\mathrm{Hg}$ гелем кремнезема, обладающим высокой сорбционной емкостью для многих катионов [28, 36, 37]. 
Вторичные кварциты и монокварциты характеризуются крайне неравномерным распределением ртути, но в целом относительно высокими значениями. При этом максимальные концентрации $\mathrm{Hg}$ отмечаются для кварцитов из поверхностных отложений современных активных термальных полей (Южно-Камбального Центрального, Нижне- и Верхне-Кошелевского), а также пород, пропаренных высокотемпературными фумаролами. Отдельные высокие содержания ртути в кварцитах, вероятно, приурочены к рудным вкраплениям и прожилкам, а также участкам интенсивного химического выщелачивания этих пород.

Данные по распределению $\mathrm{Hg}$ в опалитах неоднозначны. Опалиты из тела оползня 2007 г. в Долине Гейзеров (Камчатка), в среднем, содержат Нg на порядок выше фоновых значений для пород региона. Опалиты отличаются неоднородностью структурно-текстурных особенностей, плотностью, пористостью, различными оттенками цвета, и др. характеристиками, что говорит о существовании различных физико-химических условий на термальном поле, с которого сошел оползень. В отдельных случаях опалитизированные туфы содержат фоновые концентрации Нg. Таким образом, вторичные кварциты, опалиты, монокварциты, пропилитизированные и аргиллизированные породы активно участвуют в миграции, перераспределении и накоплении $\mathrm{Hg}$ в гидротермальных системах и на геотермальных площадях.

Гидротермальные глины. Систематическое опробование разрезов до основания толщи глин позволяют отметить следующее. Гидротермальные глины современных термоаномалий содержат концентрации ртути на 2-3 порядка выше фоновых, до ураганных значений в отдельных слоях. Максимальные значения $\mathrm{Hg}$ наиболее характерны для верхних слоев гидротермальных глин, насыщенных пиритом, реже - гематитом и др. рудными минералами. Содержания $\mathrm{Hg}$ в слоях гидротермальных глин кошелевских термальных полей существенно выше, чем паужетских, рис. 2. Верхние горизонты паужетских термальных полей сложены "синими глинами” - с большим количеством в них пирита и оксидов железа. Эти горизонты выделяются и максимальными значениями $\mathrm{Hg}-$ до $n \times 10^{-3} \%$. Остальные слои гидротермальных глин на ВерхнеПаужетском термальном поле обеднены ртутью.

Иное распределение Нg наблюдается для кошелевских термальных полей. Здесь все разрезы и все слои глин обогащены $\mathrm{Hg}$ - до очень высоких значений: $n \times 10^{-2} \%$. Верхние слои лишь в отдельных разрезах выделяются максимальными значениями. Не отмечается каких-либо закономерностей в распределении концентраций Нg на глубину. В то же время, Нижне- и Верхне-Кошелевская термоаномалии различаются уровнем концентрации $\mathrm{Hg}$ в глинах: в последней значения ниже, они стабильно

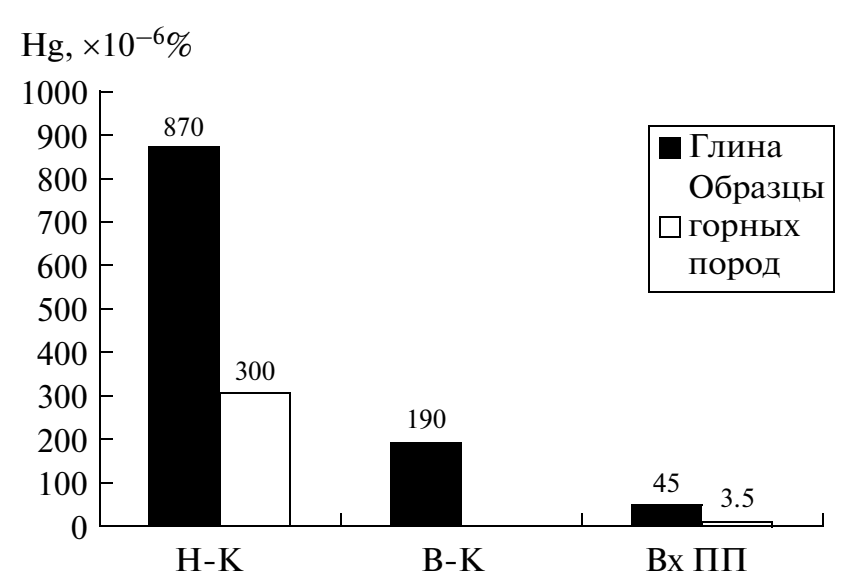

Рис. 2. Средние значения концентраций ртути в гидротермальных глинах и в образцах горных пород, извлеченных из гидротермальных глин, на Нижне-Кошелевском (Н-K), Верхне-Кошелевском (В-К) и Верхне-Паужетском (ВхПП) термальных полях.

ровные по слоям разрезов $\left((100-300) \times 10^{-6} \%\right)$, отсутствуют ураганные значения.

Кроме изучения основного субстрата гидротермальных глин, установлено содержание $\mathrm{Hg}$ в образцах горных пород (лав и туфов), находящихся внутри слоев глин и сохранивших свою первичную структуру и, в определенной степени, физические свойства. Уровень концентраций ртути в образцах пород существенно ниже, чем в глинистом субстрате. Контрольные замеры содержаний Hg в глинах и образцах пород показали, в целом, удовлетворительную сходимость результатов. При этом очевидно, что большой разброс значений концентрации $\mathrm{Hg}$ (до $\geq 100 \%$ ) в некоторых пробах объясняется, прежде всего, не ошибкой определений, а неоднородным распределением минерального вещества в этих пробах: например, резкие всплески значений могут давать отдельные зерна киновари и метациннабарита. Сульфиды $\mathrm{Hg}$ образуются в зоне гипергенеза высокотемпературных геотермальных месторождений, в частности, на Менделеева-Горячий Пляж (о-в Кунашир), Океанском (о-в Итуруп) [38, 39]. По минералогическим данным предполагается наличие киновари и, возможно, метациннабарита на НижнеКошелевском геотермальном месторождении в гидротермальных глинах [22].

Почвенно-пирокластические отложения. При проведении комплексных работ Южнокамчатско-Курильской экспедиции ИВиС ДВО РАН в 2008-2009 гг. был отмечен прогрев почвы до $90^{\circ} \mathrm{C}$ и вследствие этого сгорание растительности на площади $200 \times 200$ м вне современной термоаномалии. Участок расположен на водоразделе между ручьями Гремучий и Прямой и назван НижнеКошелевским Новым термальным полем (НКН). Предполагается, что наиболее вероятна техногенная причина образования этой новой термоано- 
(a)

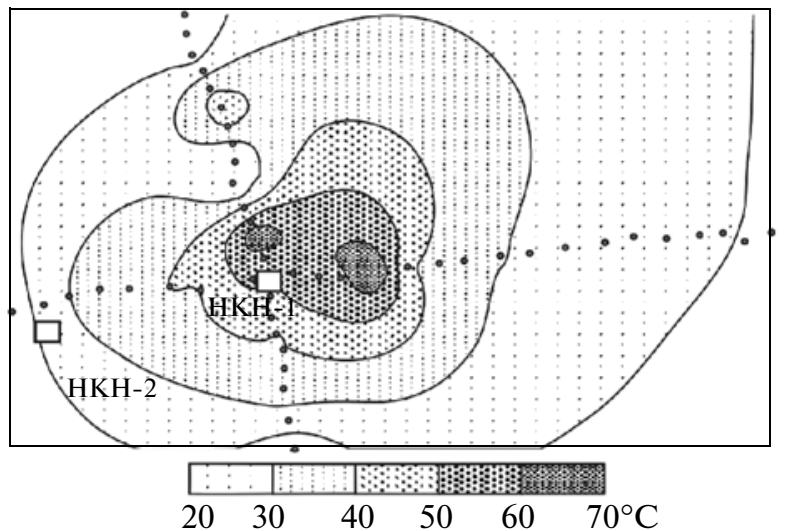

(B)

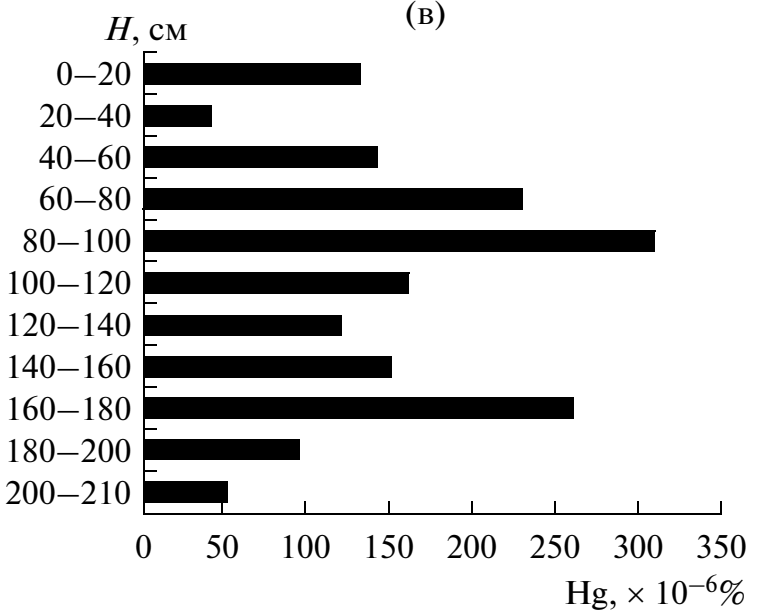

(б)

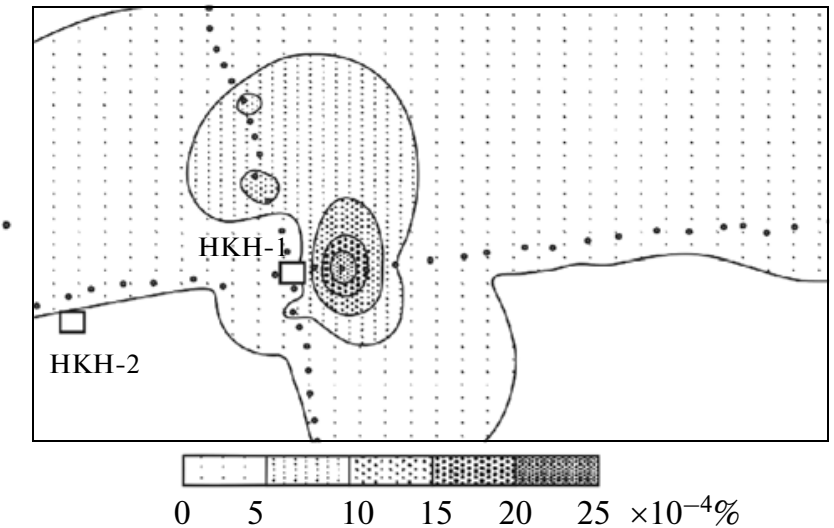

(г)

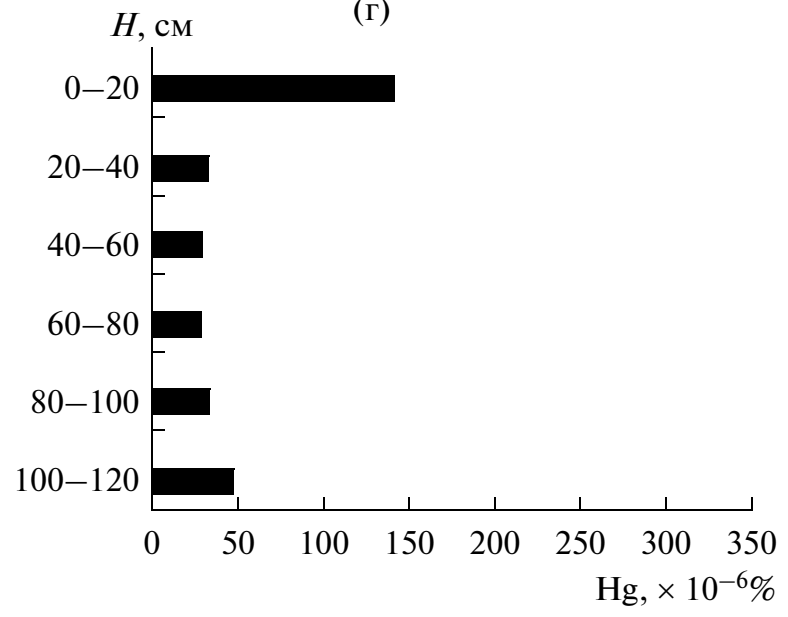

Рис. 3. Нижне-Кошелевское Новое термальное поле (НКН): а - распределение температур в почвенно-пирокластическом чехле на глубине $60-80 \mathrm{~cm}$, от 20 до $70^{\circ} \mathrm{C}$; б - распределение концентраций ртути в подпочвенном слое на глубине $20-40$ см, в интервалах значений $(0-5),(5-10),(10-15),(15-20),(20-25) \times 10^{-4} \%$; в - распределение ртути в вертикальном разрезе почвенно-пирокластических отложений, шурф НКН-1; г - то же, шурф НКН-2.

малии: нарушение обсадки в верхней части ствола разведочной геотермальной скважины, расположенной в 20 м выше границы НКН, и разгрузка парогидротерм по подошве лавового потока, падающего согласно наклону современной дневной поверхности. В связи с образованием такого феномена нами, в частности, изучено распределение ртути в почвенно-пирокластических отложениях (супесь, суглинки, захороненные почвы) в вертикальных разрезах и на площади поля, рис. 3.

В шурфе, пройденном в центральной наиболее прогретой части НКН, вследствие активизации современных геотермальных процессов почвенно-пирокластические отложения аргиллизированы, начиная с третьего слоя сверху. В пятом и последующем слоях супесь и суглинок полностью превращены в гидротермальную глину, которая в различной степени насыщена влагой. В шурфе на границе НКН признаки аргиллизации материала проявляются ближе к забою (160 см), где возрастают и температуры грунтов (от $14-15^{\circ} \mathrm{C}$ на дневной поверхности до $30^{\circ} \mathrm{C}$ у основания разреза). Разрез почвенно-пирокластических отложений в центре НКН обогащен $\mathrm{Hg}$ на всю глубину (до 2 м). Содержания $\mathrm{Hg}$ несколько снижаются в слое гидротермальных глин, отличающихся высокой влажностью. Понижаются значения концентраций и к забою шурфа, где снижается и температура субстрата (от $70^{\circ} \mathrm{C}$ в средней части до $50^{\circ} \mathrm{C}$ в основании).

Разрез на границе НКН (за пределами 20-ти градусной изотермы) характеризуется также повышенными относительно фона (в 10-15 раз) содержаниями $\mathrm{Hg}$ в суглинке и супеси почвеннопирокластических отложений. Но уровень концентраций значительно ниже, чем в прогретой части поля. Относительно высокие значения в верхнем черноземном слое могут быть случайным отклонением от данного распределения, либо отражать обычную тенденцию, когда в условиях повышенного градиента температур $\mathrm{Hg}$ отгоняется из пород и концентрируется вблизи дневной поверхности [1]. Необходимо отметить также высокую способность к сорбции ртути биологического материала - торфа, растительных остатков [6], 
чем может быть обусловлено накопление $\mathrm{Hg}$ в верхнем черноземном слое разреза.

Подпочвенный горизонт, распространенный на площади НКН и в непосредственной близости к нему, содержит $\mathrm{Hg}$ в количестве от 1 до 3-х порядков выше фоновых значений. При этом высокие концентрации образуют аномалию в центре поля. Границы ее четкие (на интервале 10-20 м) и она однозначно коррелируется с температурной аномалией. Таким образом, образование ртутногеохимической и температурной аномалий обусловлено единым источником поступления тепла и $\mathrm{Hg}$ в почвенно-пирокластические отложения геотермальным теплоносителем.

Пирит, образованный в гидротермальных глинах. Пирит выделен из гидротермальных глин с помощью шлихового анализа. Получена тяжелая фракция, состоящая на 99-95 объемных \% из зерен и агрегатов зерен пирита. Далее с помощью минералогического анализа этот концентрат был очищен от примесей, выделена монофракция пирита. Исходя из аналитических данных (см. табл. 2), примеси других минералов не влияют на уровень концентраций ртути. Необходимо отметить очень высокие значения содержаний $\mathrm{Hg}$ в пирите по всем разрезам и в каждом слое гидротермальных глин: от $n \times 10^{-4} \%$ до $n \times 10^{-2} \%$. Пирит Южно-Камбального Центрального термального поля содержит, в среднем, на порядок больше $\mathrm{Hg}$, чем пирит Нижне-Кошелевской термоаномалии. Отдельные разрезы этой геотермальной аномалии характеризуются сопоставимыми с Южно-Камбальным Центральным термальным полем концентрациями $\mathrm{Hg}$ в пирите, они вскрывают гидротермальные глины в наиболее активной части термоаномалии. Ранее было показано, что пирит Южно-Камбального Центрального термального поля характеризуется максимальными в сравнении с пиритом других полей содержаниями золота, серебра, полиметаллов, др. элементов [9]. Данный факт заслуживает повышенного внимания в связи с известной тенденцией корреляции уровня концентрации $\mathrm{Hg}$ в пирите с этими рудными элементами на эпитермальных месторождениях.

Кремнистые и карбонатные отложения. Эти отложения представлены: естественными кремнистыми осадками ("гейзеритами"), образующимися при разгрузке подземных источников, или травертинами смешанного карбонатного состава (кальцит, арагонит, кальцит + арагонит + сидерит); искусственными плащами кремнистых осадков или травертинов, образующихся при сбросе гидротерм из скважин или сепараторов на дневную поверхность; кварцевыми, кварц-карбонатными или кварц-карбонат-цеолитовыми и др. состава прожилками в туфах; опал-халцедоновыми коркамижеодами (иногда с вкраплениями сульфидов).

Содержания Hg в кремнистых осадках, образующихся на изливе парогидротерм из скважин и сепараторов Паужетского месторождения, соот- ветствуют фоновым значениям или превышают их на порядок, рис. 4. При этом более высокие содержания характерны для нижнего горизонта (слоя) “гейзерита", который включает также илистый осадок, полуразложенные или окремненные растительные остатки. Систематическое опробование этих осадков на изливах гидротерм из скважин R-120, R-106 и ГК-3 показало, что высокие значения содержаний $\mathrm{Hg}$ часто отмечаются в осадках непосредственно у зумпфов (вначале слива) и максимальные значения (до $n \times 10^{-3} \%$ ) характерны для верхних слоев отложений $[6,27]$. Это обстоятельство позволило сделать вывод о том, что источником ртути в данном случае являются термальные воды, поступающие из нижнего водоносного горизонта Паужетского геотермального месторождения.

Карбонатные отложения, часто с примесью минералов кремнезема, содержат заметно более высокие концентрации $\mathrm{Hg}$, как современные, так и палеогидротермальные. Высокие содержания $\mathrm{Hg}$ характерны для опал-халцедоновых корок-жеод, образующихся на высокотемпературных термальных полях, в среднем $-n \times 10^{-4} \%$, до $n \times 10^{-3} \%$.

Солевые отложения различного состава. Солевые отложения широко распространены на поверхности термальных полей. Они образуют корочки, ажурные, пластинчатые или комковатые минеральные структуры белого, желто-серого, бурого и др. оттенков цветов в зависимости от химического состава. Наиболее широко распространены сульфаты ряда металлов (Ca, Fe, $\mathrm{Na}, \mathrm{Mg}$ ) и кремнистые отложения (опал, халцедон). Они приурочены, как правило, к парящим грунтам и низкотемпературным (до 80-98 C) паровым струям. Соли смешанного состава (сульфаты + минералы кремнезема + + цеолиты + сульфиды + окислы и гидроокислы железа + самородная сера) образуются вокруг активных высокотемпературных фумарол. На поверхности термальных полей широко развиты современные и погребенные лимонит-гематитовые плащи мощностью до 0.5-1.0 м и площадью до $2500 \mathrm{M}^{2}$. Вещество этих отложений может быть как мягким гелеобразным, так и плотным, жестким, раскристаллизованным в гематит.

Содержания ртути в солевых отложениях контрастны: от фоновых до высоких значений $\left(n \times 10^{-3} \%\right)$. Низкими значениями, как правило, характеризуются сульфаты, высокими - соли смешанного состава, особенно концентрирующиеся вокруг фумарол. Кремнистые опаловидные отложения содержат $\mathrm{Hg}$ до $n \times 10^{-4} \%$. Железистые осадки (лимонитовые гели и лимонит-гематитовые корки), в целом, обеднены ртутью. Но отдельные значения до 5-6 раз выше фоновых. Это свидетельствует в пользу активной миграции $\mathrm{Hg}$ в этих осадках. Следует отметить, что лимонит-гематитовые плащи на Верхне-Кошелевской термоаномалии образуются за счет интенсивного 


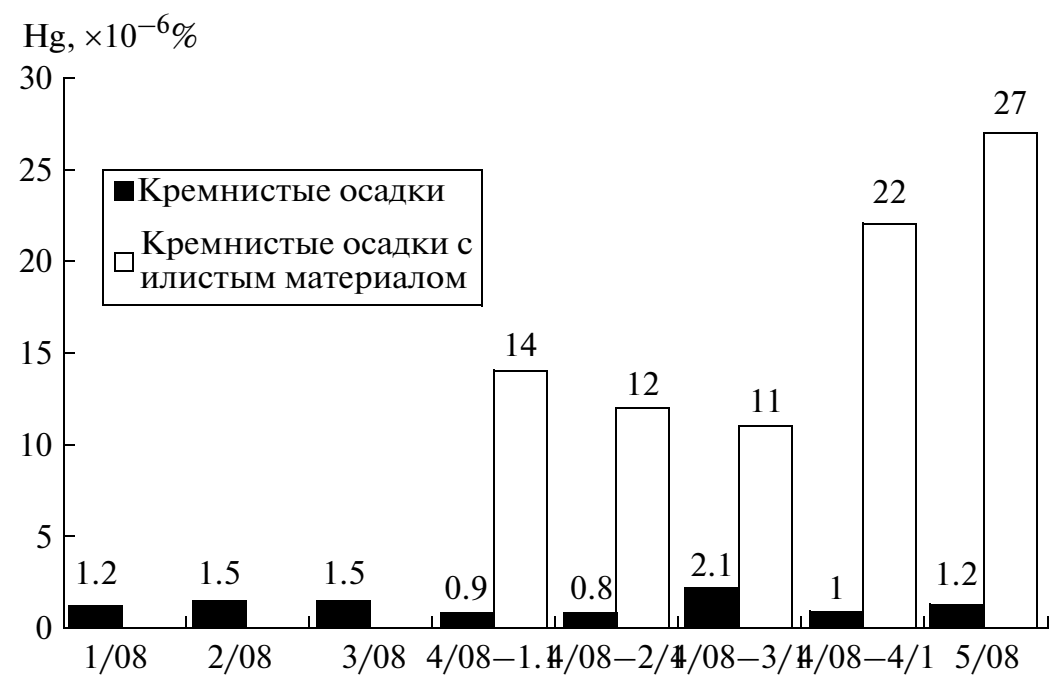

Рис. 4. Распределение ртути в кремнистых осадках (“гейзеритах”) и в кремнистых осадках с илистым материалом и остатками растительности, образующих плащ на изливе парогидротерм из скважины ГК-3 (Паужетское геотермальное месторождение). Пробы отобраны на следующем расстоянии от зумпфа скважины: $1 / 08-5$ м, 2/08 - 50 м, $3 / 08-$ 65 м (у основания водопада), 4/08 - 75 м (профиль из 4-х разрезов вкрест простирания плаща); 5/08 - 105 м (фронтальная часть плаща, образующая водопад перед рч. Быстрый).

выщелачивания железа слабокислыми холодными метеорными водами из склоновых отложений внутри кратера, вмещающего термоаномалию. Выщелачиваемые породы содержат $\mathrm{Hg}$ обычно на уровне фоновых значений и железистые осадки также содержат малые концентрации ртути.

Кремнисто-сульфидные корки из фумарол. В районе Верхне-Кошелевской термоаномалии функционирует основная термовыводящая структура - дуговой ручей Тартарары, вдоль которого в русле и по бортам расположены мощные паро-газовые струи [10]. Температуры паро-газовой смеси достигают $150^{\circ} \mathrm{C}$. На дневной поверхности разгружается сухой пар, что в совокупности с другими данными свидетельствует о наличии крупной зоны перегретого пара на глубине. Внутри жерла и вокруг устья фумарол с температурами газов на выходе от 120 до $150^{\circ} \mathrm{C}$ образуются кремнисто-сульфидные корки, желваки, трубы. Содержание ртути в них стабильно высокое и на 1-2 порядка превышает фоновые значения для твердых отложений.

Тяжелая фракция шлиховых проб аллювия. Данный материал получен с помощью шлихового анализа тонкообломочных отложений аллювия ручья Гремучий из центральной, наиболее динамичной и высокотемпературной части НижнеКошелевской термоаномалии. Необходимо отметить очень высокие содержания Нg во всех пробах. Поскольку тяжелая фракция аллювия представлена зернами минералов с большой плотностью (пирит, магнетит, гематит, самородные металлы и интерметаллические соединения, другие акцессорные), можно предполагать наличие в этих пробах минералов ртути. В пользу данного предположения свидетельствует также факт, что пирит, кото- рый, как показано нами выше, обогащен $\mathrm{Hg}$, составляет не более $20 \%$ от объема этих проб и поэтому не может давать основные содержания ртути в пробах. Ранее отмечалось, что находки сульфидов ртути имеют место на высокотемпературных геотермальных полях вулканов Менделеева (о-в Кунашир), Баранского (о-в Итуруп) и Нижне-Кошелевской термоаномалии. Таким образом, высокие содержания $\mathrm{Hg}$ в шлиховых пробах аллювия ручья Гремучий могут быть обусловлены наличием в аллювии сульфидов ртути.

\section{ОБСУЖДЕНИЕ РЕЗУЛЬТАТОВ}

Изучение распределения ртути во всех типах горных пород и гидротермально-метасоматических новообразований на примере ПаужетскоКамбально-Кошелевского геотермального (рудного) района Южной Камчатки и в сравнении с некоторыми другими районами мира (Курильские острова, Альпийский регион) показало следующее.

Горные породы (вулканогенно-осадочные, лавы, туфы, интрузивные), не затронутые гидротермально-метасоматическими изменениями, характеризуются низким уровнем содержаний $\mathrm{Hg}-$ в пределах $\left((1.0-3.8) \times 10^{-6 \%}\right.$, по [34]). Этот факт подтверждает сделанный ранее вывод о фоновом уровне концентраций ртути в первичных горных породах, вмещающих гидротермальные системы и геотермальные месторождения $[1,3]$. Расчеты показывают, что горные породы гидротермальномагматической системы при принимаемом минимальном объеме $100 \mathrm{kM}^{3}(10 \times 10 \times 1 \mathrm{kм}-$ для таких крупных систем как Кошелевская) и самом низком значении содержания $\mathrm{Hg}$ в породах $\left(1 \times 10^{-6} \%\right)$, 
этот объем пород содержит 2000 тонн $\mathrm{Hg}$. Согласно усредненным оценкам (при содержании $\mathrm{Hg}$ (1.0$3.8) \times 10^{-6} \%$ ) количество Нg составит несколько тысяч тонн во вмещающих неизмененных горных породах. Достаточно экстрагировать из них только десятую часть ртути, чтобы обеспечить накопление отмеченного выше количества $\mathrm{Hg}$ в пределах геотермального месторождения, в частности, Паужетского или Горячий Пляж, по которым приводятся соответствующие цифры в литературе [1]. Наши расчеты по объему накопленной ртути в чехле гидротермальных глин Нижне-Кошелевской термоаномалии (при среднем содержании $\mathrm{Hg} 1 \times 10^{-3} \%$ и минимальном объеме глин $200 \times 250 \times 2$ м = 100000 м $^{3}$ ) дают цифру 2 т. Таким образом, вмещающие неизмененные горные породы могут служить базовым источником $\mathrm{Hg}$, поступающей в гидротермальные системы и геотермальные месторождения, при наличии соответствующих механизмов извлечения ртути из пород; источником $\mathrm{Hg}$ для гидротермальных глин могут служить гидротермально-метасоматические породы геотермального месторождения.

Все гидротермально-метасоматические образования (пропилиты, вторичные кварциты, гидротермальные глины, отдельные минералы и разнообразные солевые отложения) характеризуются повышенными концентрациями $\mathrm{Hg}-$ от $n \times 10^{-5} \%$ до $n \times$ $10^{-2} \%$. Изучение условий накопления и перераспределения $\mathrm{Hg}$ в различных типах новообразований позволяет сделать вывод общего характера: современные геотермальные процессы служат мощным фактором привноса, миграции, накопления и перераспределения ртути в длительноживущих гидротермально-магматических системах и геотермальных месторождениях. Количество $\mathrm{Hg}$, которой обогащены измененные породы и гидротермальнометасоматические новообразования в верхних горизонтах геотермальных месторождений (при площади несколько квадратных километров и до глубины 500-1000 м), может составлять нескольких сотен тонн. Наиболее обогащена зона гипергенеза геотермальных месторождений, количество $\mathrm{Hg}$ здесь, на примере Нижне-Кошелевского месторождения, $\geq n \times 10$ тонн. Высокой сорбционной емкостью $\mathrm{Hg}$ обладают гидротермальные глины, пирит (возможно - другие сульфиды) и образующиеся на наиболее активных участках термоаномалий донные осадки, а также кремнистые отложения и соли смешанного состава. Изучение распределения и особенностей миграции ртути в зоне гипергенеза геотермальных месторождений имеет также большое экологическое значение.

Характер распределения ртути в различных типах новообразований на геотермальных месторождениях, отличающихся термодинамическими и физико-химическими параметрами, а также продолжительностью формирования (возрас- том), свидетельствует о высокой динамике процессов миграции $\mathrm{Hg}$ в пределах гидротермальномагматических систем. На высокотемпературном прогрессивном этапе развития систем происходит интенсивный привнос, накопление и перераспределение $\mathrm{Hg}$ в пределах геотермальных месторождений и термоаномалий. Особую роль в этом играет зона гипергенеза геотермальных месторождений. На регрессивном этапе происходит дальнейшая отгонка $\mathrm{Hg}$ из недр термоаномалий, но, в основном, - накопление ее в близповерхностном горизонте гидротермальных глин на субаквальном (сульфидном) геохимическом барьере и постепенная (?) миграция ртути за пределы термальных полей.

Установлено, что агентами, транспортирующими $\mathrm{Hg}$, служат гидротермальные высокотемпературные растворы и парогазовая смесь. На геотермальных месторождениях водного типа (Паужетском) Нg поступает к дневной поверхности в составе гидротерм из нижнего водоносного горизонта. На пародоминирующих месторождениях (Нижне-Кошелевском) Нg переносится перегретой (“сухой”) парогазовой смесью от кровли остывающего субинтрузивного тела диоритовых порфиритов в близповерхностные горизонты, трассируя восходящий конвективный тепловой поток. Таким образом, Нg обладает свойствами повышенной “летучести” в геотермальных системах, что было отмечено еще в работах А.А. Саукова и его учеников [40]. Это имеет принципиальное значение для изучения положения источников тепла, фазового состояния теплоносителя, динамики флюидов.

Изучение почвенно-пирокластических отложений на площади геотермальных месторождений показало, что аргиллизация служит прямым фактором концентрирования $\mathrm{Hg}$. За пределами термоаномалий и на их границах почвенно-пирокластические отложения во всех разрезах содержат $\mathrm{Hg}$, но на низком уровне - до 1 порядка выше фоновых значений. С увеличением степени аргиллизации субстрата постепенно растут концентрации $\mathrm{Hg}$ - до обычных значений в типичных гидротермальных глинах (до $n \times 10^{-3} \%$ ). Переход глин в коренные породы основания почвеннопирокластического чехла сопровождается резким уменьшением содержаний $\mathrm{Hg}$ в скальных грунтах, до фоновых значений. Все это позволяет говорить об аргиллизации как о процессе, определяющем миграцию и концентрирование $\mathrm{Hg}$ в обломочных отложениях зоны гипергенеза геотермальных месторождений. Глинистые минералы, по-видимому, обладают одной из наиболее высоких сорбционных емкостей на $\mathrm{Hg}$, а чехол гидротермальных глин служит высокодинамичным геохимическим барьером ртути.

Характер распределения и динамика процессов миграции $\mathrm{Hg}$ в гидротермальных глинах отражают относительный возраст (зрелость) гидротермаль- 
ных глин и термальных полей. Так, гидротермальные глины термальных полей Кошелевского вулканического массива содержат $\mathrm{Hg}$ в высоких концентрациях по всему разрезу толщи глин. Тенденция увеличения содержаний $\mathrm{Hg}$ в верхних слоях глин лишь намечается. Известно, что Кошелевская гидротермально-магматическая система находится на прогрессивном этапе развития [16]. Соответственно, термоаномалии массива характеризуются высокими $P-T$ параметрами и динамикой теплоносителя. Гидротермальные глины Паужетского месторождения обогащены $\mathrm{Hg}$ только на приповерхностном сульфидном геохимическом барьере, основная толща глин обеднена ртутью. Паужетская гидротермально-магматическая система в настоящее время переживает регрессивный этап, происходит охлаждение теплоносителя и вмещающих пород [9]. Таким образом, $\mathrm{Hg}$, привнесенная в чехол гидротермальных глин на высокодинамичном прогрессивном этапе, с течением времени при охлаждении гидротермальной системы выносится не только в целом из недр системы, но и отгоняется в пределах толши гидротермальных глин от ее подошвы к поверхности. Отмеченная особенность поведения $\mathrm{Hg}$ позволяет обратить внимание на фактор времени и определенную цикличность в миграции ртути в гидротермально-магматической системе.

Непосредственными источниками $\mathrm{Hg}$ на изученных геотермальных месторождениях служат термальные воды глубинных горизонтов - для Паужетского месторождения, и перегретая паро-газовая смесь, поступающая из приконтактовой зоны нагретого магматического тела диоритовых порфиритов - для Нижне-Кошелевского месторождения. Толща гидротермальных глин, залегающих вблизи дневной поверхности, на прогрессивном этапе развития термоаномалии аккумулирует ртуть, на регрессивном - служит своеобразным источником ртути в ее геохимическом цикле.

В свете изложенного, представляется следующая концептуальная геолого-геохимическая модель транспорта (геохимического цикла) ртути в структуре гидротермально-магматической системы и геотермального месторождения. $\mathrm{Hg}$ транспортируется из нижних высокотемпературных горизонтов системы в составе гидротермальных растворов и перегретой паро-газовой смеси. $\mathrm{Hg}$ экстрагируется также из вмещающих гидротермально-метасоматических пород за счет циркуляции трещинно-поровых гидротермальных растворов и постепенно (?) отгоняется из недр гидротермально-магматических систем в зону гипергенеза. Зона гипергенеза высокотемпературных геотермальных месторождений прогрессивного этапа развития служит эффективным геохимическим барьером ртути. Здесь происходит накопление $\mathrm{Hg}$ в течение прогрессивного (“кошелевского") и, вероятно, экстремального (“мутновского”) этапов. При остывании системы $\mathrm{Hg}$ отгоняется из ее недр и из нижних слоев близповерхностной толщи гидротермальных глин вплоть до фоновых значений. Происходит “вымывание" Нg из глин, кремнистых и др. осадков и транспорт ее за пределы термоаномалий глубинными (скважинными), смешанными и метеорными водами. Далее, определенная часть ртути, для оценки объема которой необходимы режимные гидродинамические исследования, поступает с инфильтрационными водами в недра гидротермальной системы. Образуется конвективная саморегулирующаяся система, в которой $\mathrm{Hg}$ служит элементом-индикатором температуры, динамики, физико-химических свойств теплоносителя и относительного возраста (зрелости) гидротермально-магматической системы, геотермального месторождения и термальных полей.

Авторы глубоко признательны Р.Г. Давлетбаеву, О.В. Ковиной, Г.П. Королевой, М.С. Чернову, М.Е. Блюмкиной, Д.З. Зухубая, В.В. Шаниной, Д.А. Черебатову, И.А. Нужкаеву, С.О. Феофилактову и другим своим коллегам по экспедиционным работам за помощь в получении фактического материала; сотрудникам аналитических лабораторий Института геохимии им. А.П. Виноградова СО РАН Л.Д. Андрулайтис и О.С. Рязанцевой и Института вулканологии и сейсмологии ДВО РАН В.П. Коростелевой за большую методическую работу; всем специалистам, принявшим участие в обсужждении основных положений статьи.

Работа выполнена при финансовой поддержке Российского фонда фундаментальных исследований (проект 10-05-00009а).

\section{СПИСОК ЛИТЕРАТУРЫ}

1. Трухин Ю.П., Степанов И.И., Шувалов Р.А. Ртуть в современном гидротермальном процессе. М.: Наука, 1986. 199 с.

2. Озерова Н.А. Ртуть и эндогенное рудообразование. М.: Наука, 1986. 232 с.

3. Рычагов С.Н., Степанов И.И. Гидротермальная система вулкана Баранского, о-в Итуруп: особенности поведения ртути в недрах // Вулканология и сейсмология. 1994. № 2. С. 41-52.

4. Нуждаев А.А., Рычагов С.Н., Степанов И.И. Ртуть в зоне гипергенеза геотермальных месторождений (Южная Камчатка) / Материалы Всероссийской научной конференции (с участием иностранных ученых) "Проблемы геохимии эндогенных процессов и окружающей среды”, 24-30 сентября 2007 г. Иркутск, 2007. Т. 3. С. 82-86.

5. Нуждаев А.А., Рычагов С.Н., Степанов И.И. Ртуть как индикатор температурных и геохимических барьеров в современных рудообразующих гидротермально-магматических системах / Вулканизм и геодинамика: Материалы IV Всероссийского симпозиума по вулканологии и палеовулканологии. Петропавловск-Камчатский: ИВиС ДВО РАН, 2009. T. 2. C. 781-785.

6. Рычагов С.Н., Нуждаев А.А., Степанов И.И. Поведение ртути в зоне гипергенеза геотермальных ме- 
сторождений (Южная Камчатка) // Геохимия. 2009. № 5. С. 533-542.

7. Сугробов В.M. Геотермальные ресурсы Камчатки, классификация и прогнозная оценка / Изучение и использование геотермальных ресурсов в вулканических областях. М.: Наука, 1979. С. 26-35.

8. Долгоживущий центр эндогенной активности Южной Камчатки. М.: Наука, 1980. 172 с.

9. Структура гидротермальной системы. М.: Наука, 1993. $298 \mathrm{c}$.

10. Вакин Е.А., Декусар З.Б., Сережников А.И., Спиченкова M.B. Гидротермы Кошелевского вулканического массива / Гидротермальные системы и термальные поля Камчатки. Владивосток: ДВНЦ АН СССР, 1976. С. 58-84.

11. Кононов В.И. Геохимия термальных вод областей современного вулканизма (рифтовых зон и островных дуг) / Труды ГИН, вып. 379. М.: Наука, $1983.216 \mathrm{c}$.

12. Писарева M.В. Зона природного пара Нижнекошелевского геотермального месторождения // Вулканология и сейсмология. 1987. № 2. С. 52-63.

13. Поляк Б.Г., Толстихин И.Н., Якуцени В.П. Изотопный состав гелия и тепловой поток - геохимический и геофизический аспекты тектогенеза // Геотектоника. 1979. № 5. С. 3-23.

14. Лебедев М.М., Декусар 3.Б. Проявление углеводородов в термальных водах Южной Камчатки // Вулканология и сейсмология. 1980. № 5. С. 93-97.

15. Белоусов В.И. Геология геотермальных полей. М.: Наука, 1978. 176 с

16. Рычагов С.Н. Эволюция гидротермально-магматических систем островных дуг / Автореф. дис. докт. геол.-МИН. наук. М.: ИГЕМ РАН, 2003. 50 с.

17. Стратегия развития топливно-энергетического потенциала Дальневосточного экономического района до 2020 г. Владивосток: Дальнаука, 2001. 112 с.

18. Жатнуев Н.С., Миронов А.Г., Рычагов С.Н., Гунин В.И. Гидротермальные системы с паровыми резервуарами. Новосибирск: Изд-во СО РАН, 1996. $184 \mathrm{c}$.

19. Lund J.W., Bloomquist R.G., Boyd T.L., Renner J. The Unated States of America Country Update / Geothermal and Mineral Recources of Modern Volcanism Areas (Proceedings of the International Kuril-Kamchatka Field Workshop, July 16-August 6, 2005). Petropavlovsk-Kamchatsky: OTTISK, 2005. P. 25-50.

20. Поздеев А.И., Нажсалова И.Н. Геология, гидродинамика и нефтегазоносность Кошелевского месторождения парогидротерм, Камчатка // Вулканология и сейсмология. 2008. № 3. С. 32-45.

21. Рычагов С.Н., Давлетбаев Р.Г., Ковина О.В. Роль гидротермальных глин и образующегося в них пирита в современных рудно-геохимических процессах на геотермальных полях (Южная Камчатка) / Проблемы геохимии эндогенных процессов и окружающей среды: Материалы Всероссийской научной конференции (с участием иностранных ученых). Иркутск: Изд-во Института географии им. В.Б. Сочавы СО РАН, 2007. Т. 3. С. 103-108.

22. Рычагов С.Н., Давлетбаев Р.Г., Ковина О.В., Королева Г.П. Характеристика приповерхностного горизонта гидротермальных глин Нижне-Кошелевского и Паужетского геотермальных месторождений // Вестник КРАУНЦ. Науки о Земле. 2008. № 2. Вып. 12. С. 116-134.
23. Сывороткин В.Л. Современный вулканизм Южной Камчатки и гидротермальный процесс / Структура гидротермальной системы. М.: Наука, 1993. С. 21-47.

24. Королёва Г.П., Ломоносов И.С., Стефанов Ю.М. Золото и другие рудные элементы в гидротермальной системе / Структура гидротермальной системы. М.: Наука, 1993. С. 238-280.

25. Сандимирова Г.П. Геохимические факторы распределения стронция и вариации его изотопного состава в гидротермальных системах / Структура гидротермальной системы. М.: Наука, 1993. С. 196-218.

26. Пампура В.Д. Геохимия гидротермальных систем областей современного вулканизма. Новосибирск: Наука, 1985. 153 с.

27. Rychagov S.N., Boikova I.A., Kalacheva E.G. et al. Artifical Siliceous Sinter Deposits of the Pauzhetsky Geothermal System / Proceedings of the Conference on Mineral Extraction from Geothermal Brines. USA, Tucson, Arizona. September, 3-6, 2006. 4 p.

28. Белоусов В.И., Рычагов С.Н., Кузьмин Ю.Д. и др. Кремнезем в высокотемпературных гидротермальных системах областей современного вулканизма // Экологическая химия. 1998. Т. 7. Вып. 3. С. 200-216.

29. Рычагов С.Н., Белоусов В.И., Главатских С.Ф. и др. Северо-Парамуширская гидротермально-магматическая система: характеристика глубокого геологического разреза и модель современного минерало-рудообразования в ее недрах // Вулканология и сейсмология. 2002. № 4. С. 3-21.

30. Нуждаев A.A. Новые результаты изучения Верхнеи Нижне- Кошелевских аномалий (Южная Камчатка) / Материалы региональной молодежной конференции "Исследования в области наук о Земле”. Петропавловск-Камчатский: Изд-во КамГУ им. Витуса Беринга, 2008.

31. Rychagov S.N., Nuzhdaev A., Stepanov I.I. Mercury as an indicator of temperature and geochemical barriers in hypergenesis zone of geothermal deposits (Kamchatka) / Proceedings World Geothermal Congress 2010. Bali, Indonesia, 25-29 April 2010.

32. Geology of Hungary (Ed. Ianos Haas). Budapest, 2001. $350 \mathrm{p}$.

33. Polona Kralj. Volcanoclastic Rocks in Borehole Tdp1/84 Trobni Dol, Eastern Slovenia // Geologija. 1999. N 41. P. $135-155$.

34. Леонова Л.Л. Геохимия четвертичных и современных вулканических пород Курильских островов и Камчатки // Геохимия. 1979. № 2. С. 179-197.

35. Ладыгин В.М., Рычагов С.Н., Васильева Ю.В. и др. Петрофизические свойства метасоматитов Паужетского месторождения парогидротерм (Южная Камчатка) // Вулканология и сейсмология. 1991. № 6. C. $95-110$.

36. Айлер $P$. Химия кремнезема (в 2-х частях). М.: Мир, 1982. 1128 с.

37. Чухров Ф.В. Коллоиды в земной коре. М.: Изд-во АН CCCP, 1955. $671 \mathrm{c}$.

38. Айдиньян Н.Х., Озерова Н.А., Волкова А.В., Шикина Г.П. К вопросу о летучести ртути и ее соединений // Геохимия. 1969. № 9. С. 251-260.

39. Знаменский В.C. Гидротермально измененные породы Мутновского (Камчатка) и Кипящего (о. Итуруп) геотермальных месторождений // Изв. АН СССР. Серия геология. 1991. № 5. С. 110-123.

40. Сауков А.А., Айдиньян Н.Х., Озерова Н.А. Очерки геохимии ртути. М.: Наука, 1972. 336 с. 